\title{
MEDIA ONLINE “MOGIGU” EFFECTIVE FOR INCREASING KNOWLEDGE ABOUT TOOTHBRUSHING ON ELEMENTARY SCHOOL
}

\author{
Joni Satria ${ }^{\mathrm{a}}$; Diyah Fatmasari ${ }^{\mathrm{b}^{*}}$ \\ a Dinas Kesehatan Sumatera Barat ; 65 A Perintis Kemerdekaan Street ; \\ Padang 25129; Indonesia \\ ${ }^{b}$ Poltekkes Kemenkes Semarang ; Tirto Agung ; Pedalangan ; \\ Semarang 50268 ; Indonesia
}

\begin{abstract}
Dental caries is a dental health problem that is widely found in Indonesia. One way to improve a child's knowledge of maintaining dental and oral health is to provide dental health education on how to brush the teeth properly using appropriate and innovative tools or media. The type of research is quasi-experiment with pretest and posttest group design, sampling technique using Slovin formula. Media to increase knowledge is media online "mogigu" and offline media with a phantom. Differences between the groups in the test with the Wilcoxon and Mann Whitney tests. The results of the paired tests showed that counseling on how to brush your teeth using phantom media and using online media "mogigu" effectively increased knowledge of how to brush the teeth, a significant pretest and posttest value of $p<0.05$. The distributions in the two groups differed significantly showed that online media "mogigu" was more effective at increasing knowledge of how to brush the teeth than phantom media value $\mathrm{p}=0.000(\mathrm{p}<0.005)$. Media online "mogigu" more effectively improves knowledge on how to brush teeth than phantom media.
\end{abstract}

Keywords: knowledge; "mogigu"; phantom

\section{Introduction}

Dental and oral health is an integral part of the overall health of the body so the maintenance of dental and oral health is important (Kemenkes, 2019). Dental and oral health cannot be separated from each other as it will affect the overall health of the body. According to the data, about $80 \%$ of Indonesians have damaged teeth for various causes, but the most common are caries or perforated teeth (Tambuwun; et al., 2014).

To prevent the occur of teeth and to maintain good oral hygiene, one needs to maintain the cleanliness of his teeth and mouth by brushing his teeth properly and regularly. Brushing your teeth is a toothbrush or other tool (e.g. coconut fiber) with and or without toothpaste. Brushing your teeth every day is a routine tooth-cleaning activity every day outside of emergencies (illness,

\footnotetext{
$\left.{ }^{*}\right)$ Corresponding Author (Diyah Fatmasari)
}

E-mail: fatmasaridiyah@gmail.com accident, crack or broken jaw, trismus or not being able to open the mouth), and other circumstances that do not allow a person to brush their teeth (Kemenkes RI, 2018)

There are many things a human can do to keep his teeth and mouth clean. One of them is the awareness and behavior of the maintenance of individual oral hygiene. Ages 6-12 are the age of primary school children is an effective age to provide information that leads to the cognitive and skills of the child (Fatmasari, Purba, \& Salikun, 2019). To improve dental and oral health maintenance efforts as well as especially in school age children needing special attention because at this age the child is in the process of growing. The state of the teeth will previously affect the development of dental health in adulthood (Prasko, Sutomo, \& Santoso, 2016). Various ways can be done to influence the health behaviors of individuals, groups, or communities, one of which can be through 
health education. Counseling is considered to improve the knowledge and attitude of the participants who follow it (Yulinda \& Fitriyah, 2018).

Knowledge is obtained as a result of stimuli captured by the five senses. Knowledge can be obtained naturally or in a planned way through the educational process. Knowledge is a very important domain for the formation of a person's behavior, the better the knowledge of how to maintain the health of a person's teeth and mouth, followed by awareness and behavior wanting to maintain the cleanliness of his teeth properly then it is more likely to prevent the caries (Tambuwun; et al., 2014).

One way to improve the child's knowledge in maintaining dental and oral health is to provide dental health education on how to brush their teeth properly and using the right and suitable tools or media (Kristianto, Priharti, \& Abral, 2018). One of the easy-to-use fortunetellers now is audiovisual media, which is an information-sharing medium that has audio (sound) and visual characteristics (images). This type of media has better capabilities because it includes both characteristics (Purnomo, 2014).

The delivery of counseling materials to the target in addition to having to comply with the method to be used must also be influenced by the absence of supporting media facilities for delivery. Demonstrations and other methods are one way of presenting information by showing the object directly or indicating a process or procedure for its implementation. This presentation is accompanied by the use of props and media as a material delivery tool. Effective counseling is given to less large (Prasko et al., 2016).

Mogigu is one of the innovations of the dental counseling method that uses audio and visual media in its presentation. Where audio involves the ear and visually involves the eyes, during counseling takes place students see and hear directly the instructions given by the counselor (Fatmasari, Santoso, Jati, \& Utami, 2013).

\section{Method}

This type of research is Experimental Quasi which is with the design of research Group Pretest-posttest Design. This design makes the sample divided into two groups. In this design, observations are made twice before the experiment and after the experiment. The sample number is 75 elementary school-aged children who are divided into 2, the intervention group gets information about online media "mogigu" which can be uploaded via Youtube media while the control group gets counseling using phantom and toothbrush. Knowledge measurement is carried out before and after education for 2 weeks. Statistical test to measure differences in 2 groups using the Mann Whitney test.

\section{Result and Discussion}

Research conducted on students of SDN 01 and SDN $04 \mathrm{Klambu}$ by providing counseling treatment on how to brush their teeth using phantom media and online media "mogigu" there are 17 question items used to increase knowledge about how to brush your teeth. At the research the condition of the sample in the study was active in following and very active in partitioning in the research.

Based on the research that has been done, the results obtained in the table below.

Table 1. Characteristic Students by Gender

\begin{tabular}{lcccc}
\hline \multirow{2}{*}{ Gender } & \multicolumn{2}{c}{ Control } & \multicolumn{2}{c}{ Intervention } \\
\cline { 2 - 5 } & $\mathrm{n}$ & $\%$ & $\mathrm{n}$ & $\%$ \\
\hline Male & 15 & 42.9 & 12 & 34.3 \\
Female & 20 & 57.1 & 23 & 65.7 \\
\hline Amount & 35 & 100 & 35 & 100 \\
\hline
\end{tabular}

Based on table 1 can be seen the most research samples are female gender. Control group by $57.1 \%$ and intervention group by $65.7 \%$.

Table 2. Characteristics Students by Age

\begin{tabular}{lcccc}
\hline \multirow{2}{*}{ Gender } & \multicolumn{2}{c}{ Control } & \multicolumn{2}{c}{ Intervention } \\
\cline { 2 - 5 } & $\mathrm{n}$ & $\%$ & $\mathrm{n}$ & $\%$ \\
\hline 10 Years & 22 & 62.9 & 21 & 60.0 \\
11 Years & 13 & 37.1 & 14 & 40.0 \\
\hline Amount & 35 & 100 & 35 & 100 \\
\hline
\end{tabular}

Based on the table 2 can be seen the most research samples are 10 years old. Control group of $62.9 \%$ and intervention group of $60 \%$.

Table 3. Distribution of student knowledge frequency before and after counseling using phantom media

\begin{tabular}{lcccc}
\hline \multirow{2}{*}{ Knowledge } & \multicolumn{2}{c}{ Before } & \multicolumn{3}{c}{ After } \\
\cline { 2 - 5 } & $\mathrm{n}$ & $\%$ & $\mathrm{n}$ & $\%$ \\
\hline Good & 9 & 26 & 18 & 52 \\
Enough & 17 & 48 & 13 & 37 \\
Less & 9 & 26 & 4 & 11 \\
\hline Amount & 35 & 100 & 35 & 100 \\
\hline
\end{tabular}


The results from table 3 show that there was an increase before counseling was given using phantom and after counseling was given using phantom categories both from $26 \%$ to $52 \%$.

Table 4. Distribution student knowledge frequency before and after being given counseling using online media "mogigu"

\begin{tabular}{lcccc}
\hline \multirow{2}{*}{ Knowledge } & \multicolumn{2}{c}{ Before } & \multicolumn{2}{c}{ After } \\
\cline { 2 - 5 } & $\mathrm{n}$ & $\%$ & $\mathrm{n}$ & $\%$ \\
\hline Good & 7 & 22 & 29 & 83 \\
Enough & 20 & 58 & 6 & 17 \\
Less & 8 & 20 & 0 & 0 \\
\hline Amount & 35 & 100 & 35 & 100 \\
\hline
\end{tabular}

The results from table 4 show that there was an increase before counseling using online media "mogigu" and after counseling which is a category well before $22 \%$ while after $83 \%$. Because the data is categorical and distribution is abnormal (non-parametric), then to know the effectiveness of "mogigu" compared to phantom used test different pairs Wilcoxon and different test not paired Mann Whitney.

Table 5. Students' knowledge test results before and after counseling using phantom media.

\begin{tabular}{lccc}
\hline Knowledge & $\mathrm{Z}$ & $\mathrm{p}$-value & Statement \\
\hline $\begin{array}{l}\text { Pretest } \\
\text { Posttest }\end{array}$ & -2.977 & 0.003 & $\begin{array}{c}\text { There are } \\
\text { Difference }\end{array}$ \\
\hline
\end{tabular}

Based on the table above, the calculation result Wilcoxon rank test shows, value $\mathrm{p}=0.003$ which is $<0.05$. Ho was rejected, meaning there was a difference in students' knowledge before and after being given counseling using phantoms.

Students' knowledge of dental health, especially how to brush their teeth before being given knowledge on how to brush their teeth by talking method with phantom media and after counseling using phantom media is increased.

Increased knowledge occurs because at the time of counseling using phantom students demonstrated how to brush their teeth well and properly. This shows that providing information using interesting demonstrations and a pleasant atmosphere can make it easier for respondents to receive the information provided (Hestiani, Yuniar, \& Eka Meiyana Erawan, 2017).

According to Susilawati, Damayanti, \& Azhari (2017), in counseling, the materials provided must be tailored to the objective. The material (knowledge) given at the time of counseling can be distinguished based on the grade level, for example, grades IV and $\mathrm{V}$ students who are 10-11 years old, the mindset has been somewhat developed, so the right counseling material is to use props in the delivery of materials. The props used in this study are phantom dental media used to improve students' knowledge of how to brush their teeth as a means of providing information on how to brush their teeth well and properly to students.

This research is in line with research conducted by (Hestiani et al., 2017) which states that there has been a change in students' knowledge before and after counseling using demonstration methods. And this research is also in line with research conducted by (Aritonang dan Purba, 2017) in the study it can be concluded that there was a significant change in the knowledge of students given counseling using phantom media.

Table 6. Different test results Knowledge students before and after being given counseling using online media "mogigu"

\begin{tabular}{lccc}
\hline Knowledge & $\mathrm{Z}$ & $\mathrm{p}$-value & Statement \\
\hline $\begin{array}{l}\text { Pretest } \\
\text { Posttest }\end{array}$ & -4973 & 0.000 & $\begin{array}{l}\text { There are } \\
\text { Difference }\end{array}$ \\
\hline
\end{tabular}

Based on the table above, the calculation result Wilcoxon rank test shows, value $p=0.000$ that is $<0.05$. Ho was rejected meaning there was a difference in students' knowledge scores before and after being given counseling using the online media "mogigu"

The knowledge of students before being given counseling using audiovisual media or in this case online media "mogigu" and after counseling, there is an increase in monitoring. This occurs because online media "mogigu" uses media involving audio and visual. Where audio involves the ear while the visuals involve the eyes as senses Yulinda and Fitriyah (2018). This is also in accordance with the opinion expressed by Notoatmodjo (2010) which states that the senses that channel knowledge a lot are the eyes around $(75 \%-80 \%)$ This study is in line with research conducted by (Fatmasari et al., 2019) which mentions that the use of online media "mogigu" is effective in improving students' skills because at the time of counseling on how to brush their teeth see and listen directly to the instructions given so that the information obtained will be more easily received and digested by the child. 
Table 7. Differences knowledge of students who are given counseling with media phantom and online media "mogigu"

\begin{tabular}{|c|c|c|c|c|}
\hline Var & & $\mathrm{n}$ & p-value & Statement \\
\hline \multirow{2}{*}{ Knowledge } & $\begin{array}{l}\text { Media } \\
\text { Phantom }\end{array}$ & 35 & \multirow{2}{*}{0.000} & \multirow{2}{*}{$\begin{array}{l}\text { There is a } \\
\text { difference } \\
\text { between } \\
\text { the media } \\
\text { phantom } \\
\text { and online } \\
\text { "Mogigu" }\end{array}$} \\
\hline & $\begin{array}{l}\text { Media } \\
\text { Online } \\
\text { "Mogigu" }\end{array}$ & 35 & & \\
\hline
\end{tabular}

Based on the table above it can be known that these results lead to a difference in the increased knowledge of students given phantom media and online media "mogigu". Based on the different tests not paired using Mann Whitney obtained p-value $0.000<(0.005)$, this shows that online media "mogigu" more effectively improves the knowledge of brushing the teeth of elementary school students.

Based on the effectiveness test results it is known that online media "mogigu" is more effective than phantom media in knowing the changes in students' yearning on how to brush their teeth with p-value $(0.000<0.05)$ which means that online media "mogigu" is more effective in influencing students' knowledge of how to brush their teeth, because at the time of research children were more enthusiastic about counseling when using online media "mogigu" and well receivable by students. This medium offers more interesting and non-monotonous counseling, counseling using this medium offers motion, image and sound compared to counseling using phantom that uses only the voice of counseling, because this medium is relatively new some students have a great curiosity about the content of the video and see the video until it is finished seriously.

This is supported by research Muthia, Fitriangga, Syarifah, \& Yanti (2016), the senses that channel a lot of knowledge into the brain are the eyes (approximately $75 \%$ to $87 \%$ ), while $13 \%$ to $25 \%$, human knowledge is obtained and channeled through other senses. The media should be able to stimulate or enter information through various senses. The more stimulated the information will be. Online media "mogigu" provides stimulation through the eyes and ears. The combination of information channels through the eyes that reach $75 \%$ and ears $13 \%$ will provide good enough stimulation so as to provide optimal results, as well as research Muthia et al. (2016) states counseling that is interesting and involves more senses will increase one's knowledge.

\section{Conclusion and Suggestion}

Based on the results of research on the effectiveness of counseling brushing demonstrations using phantom and online media "mogigu" against knowledge on how to brush their teeth in students of SDN 01 and SDN 04 Klambu Grobogan District in 2020 can be concluded that differences in the value of knowledge on how to brush your teeth before and after counseling using phantom media. There are differences in the value of knowledge on how to brush your teeth before and after counseling are given using online media "mogigu". This study online media "mogigu" was more effective compared to phantom media in influencing students' knowledge of how to brush their teeth with a significant score of 0.000 $(\mathrm{p}<0.005)$.

\section{Acknowledgments}

Thank you to the SD N 01 Klambu, SD N 04 Klambu who have helped this research, for the Poltekkes Kemenkes Semarang, who have contributed to this research and published this research journal.

\section{References}

Aritonang dan Purba. (2017). Gambaran Efektifitas Penyuluhan Dengan Media Poster Dan Phantom Gigi Terhadap Tingkat Pengetahuan Tentang Cara Menyikat Gigi Yang Baik dan Benar Pada Siswa/i Kelas IV SDN 065015 Kemenangan Tani. 177-180.

Fatmasari, D., Purba, A., \& Salikun, S. (2019). MEDIA PERMAINAN TEBAK GAMBAR EFEKTIF DALAM PENINGKATAN PENGETAHUAN DAN TINDAKAN MENYIKAT GIGI DIBANDINGKAN MEDIA BOOKLET. Jurnal Kesehatan Gigi, 6(1), 76. https://doi.org/10.31983/jkg.v6i1.4447

Fatmasari, D., Santoso, B., Jati, W., \& Utami, D. (2013). Mogigu (menggosok gigi asyik dengan lagu) to increase brushing teeth of the elementary school. Jurnal of Applied Health Management and Technology, (5), 16 - 22. Retrieved from http:// ejournal.poltekkes-smg.ac.id/ojs/in dex.php/JAHMT/article/view/5306

Hestiani, Yuniar, N., \& Eka Meiyana Erawan, P. 
(2017). EFFECTIVENESS OF DEMONSTRATION METHOD (TEETH BRUSHING) TO IMPROVING THE KNOWLEDGE, ATTITUDE AND ACTION RELATED PREVENTION OF DENTAL CARIES AMONG 4 th AND 5 th GRADE STUDENTS IN RANTEANGIN DISTRICT NORTH KOLAKA REGENCY 2016. Jurnal Ilmiah Mahasiswa Kesehatan Masyarakat, 2(5), 1-10.

Kemenkes. (2019). KEPUTUSAN MENTERI KESEHATAN REPUBLIK INDONESIA NOMOR HK.01.07/MENKES/189/2019. 22, 1-8.

Kristianto, J., Priharti, D., \& Abral, A. (2018). Efektifitas Peyuluhan Kesehatan Gigi Dan Mulut Dengan Media Video Melalui WhatsApp Dalam Meningkatkan Derajat Kesehatan Gigi Dan Mulut Di Panti Asuhan Yos Sudarso Jakarta. Quality: Jurnal Kesehatan, 12(1), 8 - 13. https://doi.org/10.36082/qjk.v12i1.24

Muthia, F., Fitriangga, A., Syarifah, ;, \& Yanti, N. (2016). Nomor 4. In Jurnal Cerebellum (Vol. 2). Retrieved from https://jurnal.untan.ac.id/index.php/jfk/ article/view/23546

Notoatmodjo, S. (2010). Promosi Kesehatan, Teori \& Aplikasi, ed. revisi 2010. Jakarta: Rineka Cipta. https:// doi.org/10.1108/JMTM-03-2018-00 75

Penelitian dan Pengembangan Kesehatan Kementerian Kesehatan RI. (2018). Laporan Riskesdas 2018. Journal of Chemical Information and Modeling, 53(9), 181-222. https://doi.org/10.1017/СВO97811074153
24.004

Prasko, Sutomo, B., \& Santoso, B. (2016). Penyuluhan Metode Audio Visual Dan Demonstrasi Terhadap Pengetahuan Menyikat Gigi Pada Anak Sekolah Dasar. Jurnal Kesehatan Gigi, 3(2), 53 - 57. Retrieved from http:// ejournal.poltekkes-smg.ac.id/ojs/in dex.php/jkg/article/viewFile/1784/476

Purnomo, J. (2014). Penggunaan Media Audio-Visual Pada Mata Pelajaran Ilmu Pengetahuan Alam Di Sekolah Menengah Pertama Negeri. Jurnal Teknologi Pendidikan Dan Pembelajaran, 2(2), 127 144.

Susilawati, S., Damayanti, M. A., \& Azhari, suhardjo R. I. (2017). Pengaruh Penyuluhan Terhadap Tingkat Pengetahuan Siswa Tentang Kesehatan Gigi Dan Mulut Yang Dipengaruhi Radiasi. Jurnal Pengabdian Kepada Masyarakat, 1(6), 398-401.

Tambuwun; Harapan;, \& Amuntu. (2014). HUBUNGAN PENGETAHUAN CARA MEMELIHARA KESEHATAN GIGI DAN MULUT DENGAN KARIES GIGI PADA SISWA KELAS I SMP MUHAMMADIYAH PONE KECAMATAN LIMBOTO BARAT KABUPATEN GORONTALO. Jurnal IImiah Perawat Manado.

Yulinda, A., \& Fitriyah, N. (2018). Efektivitas Penyuluhan Metode Ceramah Dan Audiovisual Dalam Meningkatkan Pengetahuan Dan Sikap Tentang sadari di SMKN 5 Surabaya. Jurnal Promkes, 6(2), 116-128. 